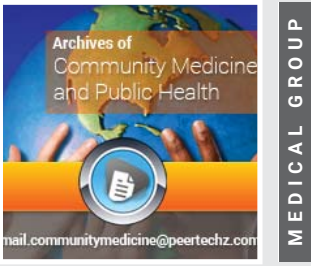

\title{
Why should everybody learn Last Aid to provide end-of-life
}

\section{care?}

\author{
Georg Bollig ${ }^{1-3 *}$ and Erika Zelko ${ }^{3-5}$ \\ 'Medical Research Unit, Institute of Regional Health Research, University of Southern Denmark, 6200 \\ Aabenraa, Denmark \\ ${ }^{2}$ Palliative Care Team, Medical Department Sønderborg/Tønder, South Jutland Hospital, 6400 \\ Sønderborg, Denmark \\ ${ }^{3}$ Last Aid Research Group Europe (LARGE), Russia \\ ${ }^{4}$ Institute of palliative medicine and care, Medical Faculty Maribor, Taborska ulica 8, 2000, Maribor, \\ Slovenia \\ ${ }^{5}$ Public Health Centre Ljubljana, Metelkova ulica 9, 1000, Ljubljana
}

Received: 25 August, 2020

Published: 01 September, 2020

*Corresponding author: Georg Bollig, Medical Research Unit, Institute of Regional Health Research, University of Southern Denmark, 6200 Aabenraa, Denmark, E-mail: bollig.georg@gmx.de ORCID: https://orcid.org/0000-0002-0367-5295 https://www.peertechz.com

Check for updates
Today most people would like to die at home [1]. Although the majority of people would prefer to die at home most people die in institutions as hospitals or nursing homes [25]. Main barriers for home death are present problems like breathlessness and most important lack of relatives. From our experience in palliative care relatives are often afraid to take care of dying people at home. Most relatives are not familiar where to get available professional support from the healthcare system and do not know how to contact and cooperate with specialised palliative care teams at home. Along with the demographic change experts have proposed an increased demand for palliative care in the future [6]. The increased demand for palliative care cannot be met by professional palliative care teams alone. Worldwide, there is a limited number of specialist palliative teams offering care to the patients at the end of their life, which means that many people receive palliative care from a primary care provider with help of their relatives [7]. Surveys over the last decade have suggested that the general public has a lack of knowledge and a negative perception towards palliative care [8-10]. In order to enable more people to die at home the cooperation between relatives, neighbours and the professional health carers has to be established and improved. According to Kellehear palliative care is a public health issue and is everyone's business [11,12]. That means that professionals and citizens should work together in what Kellehear calls compassionate communities
$[11,12]$. Citizens should receive public palliative care education in order to be prepared to care for dying people at home. The so-called public knowledge approach as proposed by Bollig $[13,14]$ seeks to transform palliative care knowledge into public knowledge. That means that every citizen should have a basic knowledge about palliative care (Last Aid) like every citizen should have basic knowledge about first aid in order to be able to respond to accidents and emergencies. The Last Aid course can provide basic palliative care knowledge throughout the entire public and thus form the knowledge base of compassionate communities. In some countries as for example in Germany people are obliged to provide first aid when approaching an accident or emergency. From our point of view citizens should also be obliged to participate in palliative care provision for dying people at home within their boundaries of skills and abilities.

Last Aid courses have been created to inform the public about palliative care and to encourage an open public discussion about death and dying. They inform people about what they can do to relieve suffering and provides information where are citizens can get help from professionals [15]. Last Aid courses have been introduced to the public in the year 2015. They have been piloted in Germany Norway and Denmark. Experiences from the courses show that people like to talk about death and dying and that they appreciate to learn the basics of palliative 
care provision within the short Last Aid course with the duration of four teaching lessons ( 45 minutes each) within 3 $1 / 2$ hours [15]. Last Aid courses are feasible and well accepted by the public in many countries [14]. A recent pilot study has shown that special Last Aid courses for children and teenagers are very much appreciated by the participants and that the majority of children and teenagers want to talk about death and dying [16]. Last Aid should therefore be a part of life-long learning in the same way this is true for first aid. Last Aid training should thus start in school.

At present 16 countries participate in the International Last Aid working group [17]. More than 26,000 citizens have been taught Last Aid and more than 2000 Last Aid course instructors have been educated. In 2019 the Last Aid research group Europe (LARGE) has been established chaired by Drs. Zelko and Bollig. At present scientific evaluation on the effects of Last Aid courses on citizens is ongoing.

From our personal experience with Last Aid courses and the at present available scientific evidence on the topic we propose that the implementation of Last Aid courses in the community may have huge effects on the willingness and ability of citizens to participate in palliative care provision at home in the future. Further research will show the impact of public palliative care education and Last Aid courses for citizens on the number of home deaths and the quality of end-of-life care at home.

The COVID-19 pandemic has shown that the professional health careers do not have the capacity to provide adequate care and palliative care for all people dying in nursing homes or at home. Therefore, we assume that public palliative care education done by Last Aid courses may have a positive effect on end of life care especially in situations like the COVID-19 pandemic where resources of professional healthcares are scarce.

With a minimum of palliative care education as provided by Last Aid courses the public might be much better prepared to face end-of-life situations and to participate in palliative care at home. This might contribute to better palliative care in everyday situations and in unusual situations like the current COVID-19 pandemic.

\section{References}

1. Gomes B, Higginson IJ, Calanzani N, Cohen J, Deliens L, et al. (2012) Preferences for place of death if faced with advanced cancer: A population survey in England, Flanders, Germany, Italy, The Netherlands, Portugal and Spain. Ann Oncol 23: 2006-2015. Link: https://bit.ly/32HReNE
2. Abba K, Lloyd-Williams M, Horton S (2019) Discussing end of life wishes the impact of community interventions? BMC Palliat Care 18: 1- 11. Link: https://bit.ly/32KbaiF

3. Gomes B, Calanzani N, Koffman J, Higginson IJ (2015) Is dying in hospital better than home in incurable cancer and what factors influence this? A population-based study. BMC Med 13: 1-14. Link: https://bit.ly/3ICeDsw

4. Cabañero-Martínez MJ, Nolasco A, Melchor I, Fernández-Alcántara M Cabrero-García J (2019) Place of death and associated factors: A populationbased study using death certificate data. Eur J Public Health 29: 608-615. Link: https://bit.ly/2YTYsNf

5. Yang L, Sakamoto N, Marui E (2006) A study of home deaths in Japan from 1951 to 2002. BMC Palliat Care 5: 1-9. Link: https://bit.ly/31M6Dgp

6. Etkind SN, Bone AE, Gomes B, Lovell N, Evans CJ, et al. (2017) How many people will need palliative care in 2040? Past trends, future projections and implications for services. BMC Medicine 15: 102. Link: https://bit.ly/3beTZcV

7. World Health Organization and Worldwide Palliative Care Alliance (2014) Global Atlas of Palliative Care at the End of Life. Worldwide Palliative Care Alliance). Link: https://bit.ly/2YU15i5

8. Mcllfatrick S, Hasson F, McLaughlin D, Johnston G, Roulston A, et al. (2013) Public awareness and attitudes toward palliative care in Northen Ireland. BMC Palliat Care 12: 34. Link: https://bit.ly/32N3dtn

9. Westerlund C, Tishelman C, Benkel I, Fürst CJ, Molander U, et al. (2018) Public awareness of palliative care in Sweden. Scand J Public Health 46: 478-487. Link: https://bit.ly/34RZZao

10. Gopal KS, Archana PS (2016) Awareness, knowledge and attitude about palliative care, in general, population and health care professionals in tertiary care hospital. Int J Sci Study 3: 31-35. Link: https://bit.ly/3hMTXvv

11. Kellehear A (2013) Compassionate communities: end-of-life care as everyone's responsibility. Q J Med 106: 1071-1075. Link: https://bit.ly/2GhL4w7

12. Kellehear A (2005) Compassionate Cities. Public health and end-of-life care Routledge, Oxfordshire.

13. Bollig G (2010) Palliative Care für alte und demente Menschen lernen und lehren. LIT-Verlag, Berlin 2010. http://www.lit-verlag.de/isbn/3-643-90058-6

14. Bollig G, Brandt F, Ciurlionis M, Knopf B (2019) Last Aid Course. An Education For All Citizens and an Ingredient of Compassionate Communities. Healthcare (Basel) 7pii: E19. Link: https://bit.ly/2QFYR1c

15. Bollig G, Kuklau N (2015) Der Letzte Hilfe Kurs - ein Angebot zur Verbesserung der allgemeinen ambulanten Palliativversorgung durch Information und Befähigung von Bürgerinnen und Bürgern. Z Palliativmed 16: 210-216. Link: https://bit.ly/34S7oXa

16. Bollig G, Pothmann R, Mainzer K, Fiedler H (2020) Children and Teenagers Want to Tal About death and Dying - Experiences from Pilot-Couyrses Last Aid for Kids/Teens from 8-16 Years. Z Palliativmed 21: 253-259.

17. Letzte Hilfe. Link: https://bit.ly/2QJoEpi

Copyright: @ 2020 Bollig G, et al. This is an open-access article distributed under the terms of the Creative Commons Attribution License, which permits unrestricted use, distribution, and reproduction in any medium, provided the original author and source are credited.

Citation: Bollig G, Zelko E (2020) Why should everybody learn Last Aid to provide end-of-life care? Arch Community Med Public Health 6(2): 198-199. 